\title{
PEMAHAMAN TEOLOGI ISLAM MASYARAKAT TENTANG PERAN ULAMA \\ (Studi Banding Masyarakat Desa Cibitung Kecamatan Sagaranten Kabupaten Sukabumi dan Kelurahan Cibangkong Kecamatan Batununggal Kota Bandung)
}

\author{
Oleh: \\ Paridah Napilah $^{1}$, Ahmad Gibson Albustomi ${ }^{2}$ \\ Universitas Islam Negeri Sunan Gunung Djati Bandung
}

\begin{abstract}
Abstrak
Dalam kehidupan masyarakat Islam ada beberapa hal yang dipandang menempati kedudukan dan otoritas keagamaan setelah Nabi Muhamad SAW sendiri. Salah satu hadist Nabi yang popular menyatakan bahwa ulama adalah pewaris para Nabi (alulama waratsah al-anbiya). Ulama merupakan tokoh yang dihormati oleh masyarakat Islam dan pendapat-pendapat mereka dianggap mengikat dalam berbagai masalah, tidak hanya pada masalah keagamaan saja, melainkan dalam berbagai masalah lainnya. Penelitian ini bertolak dari adanya perbedaan pemahaman antara masyarakat pedesaan mengenai peran Ulama yang bertempat di Desa Cibitung dan masyarakat perkotaan yang berada di Kelurahan Cibangkong. Masyarakat Desa Cibitung memahami bahwa peran ulama tidak ada batasnya, Ulama berperan dalam berbagai permasalahan baik agama, ekonomi dan sosial. Sedangkan masyarakat kelurahan Cibangkong sedikit bergeser pemahamannya bahwa Ulama berperan dalam masalah yang ada kaitannya dengan keagamaan saja. Dari hasil analisa yang dilakukan, maka diproleh kesimpulan bahwa terdapat perbedaan pemahaman teologis tentang peran ulama antara masyarakat pedesaan dan masyarakat perkotaan, yang mana masyarakat pedesaan memahami bahwa peran ulama begitu besar dalam kehidupan baik dalam masalah agama, sosial dan ekonomi. Sedangkan masyarakat perkotaan memahami peran ulama hanya dalam masalah yang berkaitan dengan kontek agama.
\end{abstract}

Kata Kunci: Pemahaman Teologi Islam, Peran Ulama

\begin{abstract}
In the life of the Islamic community there are several things that are seen as occupying religious position and authority after the Prophet Muhammad himself. One of the popular hadiths of the Prophet states that the ulama were the heirs of the Prophets (al-
\end{abstract}


ulama waratsah al-anbiya). Ulama are figures who are respected by the Islamic community and their opinions are considered binding in various problems, not only in religious matters, but in various other problems. This study departs from the differences in understanding between rural communities regarding the role of Ulama in Cibitung Village and urban communities in Cibangkong Village. Cibitung Village Community understands that the role of ulama is limitless, Ulama plays a role in various problems, both religious, economic and social. Whereas the community of Cibangkong village has slightly shifted its understanding that Ulama play a role in issues that have only to do with religion. From the results of the analysis carried out, it was concluded that there were differences in theological understanding of the role of ulama between rural communities and urban communities, in which rural communities understood that the role of ulama was so great in life both in religious, social and economic matters. Whereas the urban community understands the role of the ulama only in matters relating to the context of religion.

Keywords: Understanding of Islamic Theology, Role of Ulama

\section{A. Pendahuluan}

Setelah Nabi Muhammad, ulama dipandang sebagai otoritas kedua setelah beliau. Hal ini terbukti dalam hadist yang menyatakan bahwa ulama ialah pewaris para Nabi (al-ulama' waratsah al-anbiya'). Dengan demikian para ulama begitu dihormati oleh setiap umat muslim, dan apa yang terucap dari mulut ulama diyakini mengikat ke segala permasalahan umat, sehingga tidak terbatas pada koridor agama saja.

Dalam konteks penduduk pedesaan Islam, ulama telah mempertahankan kedudukannya dan menegakkan institusinya sebab tanpa adanya institusi keulamaan dalam doktrin Islam tidak dapat di tegakkan dan umat Islam tidak bisa mencapai tujuan keagmaan mereka, ulama biasanya mnjabarkan doktrin Islam melebihi jangkauan geografis dan generasi. ${ }^{1}$

Desa Cibitung merupakan desa yang berada di Kecamatan Sagaranten Kabupaten Sukabumi, jarak dari Kota ke Desa Cibitung sekitar $70 \mathrm{~km}$. Dalam aspek keagamaan masyarakat Desa Cibitung sepenuhnya beragama Islam, sehingga kegiatan keagamaanpun berjalan sangat baik seperti adanya kegiatan pengajian ibu-ibu dan bapak-bapak dari setiap kampungnya rutin dilakukan. Masyarakat Desa Cibitung sudah terbiasa mendapatkan bimbingan keagamaan atau bimbingan masalah lainnya dari

\footnotetext{
${ }^{1}$ Dr. Hiroko Horikoshi, Kyai dan Perubahan Sosial, Jakarta 1987, hlm. 148 - 149
} 
seorang tokoh agama yang dianggap memiliki kemampuan lebih tentang agama, sehingga masyarakat setempat memiliki kebiasaan unik yaitu menganggap bahwa ulama atau yang disebut oleh masyarakat setempat Kyai sebagai panutan serta solusi dari permasalahan kehidupan sosial. Karena mereka menganggap bahwa ulama atau Kyai sebagai salah satu tokoh yang dianggap istimewa dan yang paling dekat dengan Allah SWT. Sehingga ketika masyarakat mendapat permasalah hidup yang dianggap mampu memebrikan pengarahan dan solusi dengan mendatangi tokoh ulama atau Kyai. Hasil observasi dilapangan banyak masyarakat Cibitung yang mendatangi ulama karena ulama menjadi pusat kehidupan masyarakat dalam berbagai aspek yaitu pertama, masyarakat yang ingin memperdalam ilmu agama atau ada permasalahan dalam paham keagamaan mereka sudah terbiasa mendatangi langsung tokoh ulama setempat. Kedua, ketika usahanya lancer, mereka mendatangi ulama/Kyai karena mempercayai bahwa doa seorang Kyai itu dikabulkan oleh Allah SWT. Ketiga, masyarakat yang mengalami sakit, seperti halnya sakit kepala, mereka meminta doa untuk kesembuhan sakitnya kepada ulama karena ulama dianggap orang yang shaleh dan keberadaannya dekat dengan Allah. Keempat, adanya permasalahan dalam rumah tangga seperti perceraian, perselisihan antara suami Istri yang dianggap menjadi penengah dalam masalah dan dipercaya sebagai solusi dalam menyelesaikan permasalahan dengan mendatangi ulama/Kyai.

Masyarakat Cibitung tergolong masyarakat Islam tradisional dan merupakan masyarakat yang sudah terbiasa mendapatkan pemahaman keagamaan dari tokoh agama yang dianggap memiliki kemampuan lebih tentang agama. Ulama adalah salah satu pilar moral utama dalam masyarakat Muslim. Bila pilar itu miring, apalagi roboh, maka akan goyah atau runtuk punahlah umat Muslim. Bila umat awam melakukan kesalahan, mungkin bisa dipahami, tetapi jika ulama yang memahami agama membuat kekeliruan, bisa fatal akibatnya, sebagaimana kata Syekh Yusuf al-Maqasari; "kekeliruan orang-orang tak beragama mungkin lebih baik dari pada kesalahan dari pada kesalahan yang dibuat oleh mereka yang pintar dalam hal agama.

Seiring dengan perkembangan zaman, biasanya pemahaman juga berkembang sesuai dengan perkembangan kemampuan dan pengalaman masyarakat. Karena sebagian dari mereka sudah mengikuti pendidikan yang mana semakin bertambah pengetahuan seseorang tentu semakin baik pemahaman khsususnya dalam bidang agama. Namun dalam perkembangannya, pemahaman keagamaan masyarakat khususnya yang ada 
di Cibitung masih masih meyakini bahwa seorang ulama atau Kyai sebagai serang tokoh yang di anggap penting oleh masyarakat dalam kehidupannya.

Selain itu pemahaman ulama dikalangan masyarakat perkotaan sedikit bergeser dari pemahaman masyarakat yang ada di pedesaan. Masyarakat perkotaan pada umumnya hanya menjadikan ulama sebagai petugas masjid dan yang mengisi pengajian di waktu tertentu. Karena masyarakat perkotaan identik dengan masyarakat yang berpikir rasional dan sekuler sehingga pemahaman agama kurang dikalangan masyarakat perkotaan. Selain itu masyarakat perkotaan dekat dengan sisitem informasi sehingga menjadikan mereka terbiasa mendapatkan kajian-kajian dari media sosial tanpa harus mendatangi para tokoh ulama setempat. Hal ini berujung pada kurangnya peran seorang ulama dalam kehidupan masyarakat perkotaan. Seperti halnya di daerah Kota Bandung tepatnya Kelurahan Cibangkong Kecamatan Batununggal Kota Bandung. Karena keberadaan daerah ini berada ditengah Kota terlihat bahwa masyarakat disini sifatnya individualis dan kebanyakan dari mereka sibuk bekerja dan lebih mementingkan pekerjaannya dibandingkan dengan mengikuti kegiatankegiatan keagamaan. Maka dalam hal ini terlihat adanya perbedaan anatara masyarakat Cibitung yang memiliki cara beragama khas yang menjadikan ulama tokoh yang diangap dalam kehidupan mereka dibandingkan masyarakat Kota Bandung yang dalam kehidupannya masih kurang mengutamakan peranan seorang ulama.

\section{B. Hasil dan Pembahan}

1. Pemahaman Teologi Islam Masyarakat Pedesaan tentang Peran Ulama

a. Pemahaman Teologi Islam Masyarakat Pedesaan Tentang Ulama

Ulama merupakan tokoh yang memiliki posisi yang sangat tinggi di masyarakat pedesaan, dan memiliki tugas yang sangat penting seperti halnya para Nabi. Sebagaimana yang di ungkapkan oleh $\mathrm{H}$. saefullah beliau merupakan seorang masyarakat di lingkungan Desa Cibitung ia mengemukakan bahwa ulama merupakan pewaris para Nabi yang memiliki tugas seperti halnya Nabi untuk memimpin umat. Selanjutnya menurut $\mathrm{H}$. Maman merupakan tokoh agama/sesepuh di Desa Cibitung menjelaskan bahwa ulama merupakan orang yang memiliki ciri-ciri disiplin dalam kehidupannya, sesuai ayat dalam al-Qur'an "Innama yahsalloha min ibadihil ulama” yang disebut dengan ulama ia memiliki sifat atau ciri-ciri yang 
memiliki ilmu dan orang yang takwa pada Allah. Selanjutnya ia menjelaskan bahwa ulama itu ada tiga bagian yaitu:

1) Ulama yang dinamakan Ashabut fatwa

2) Ulama yang lebih mengenal Allah atau para hukama, yaitu orang yang mengerti hukum

3) Ulama yang mempunyai rasa kasih sayang terhadap umat

H. Maman menjelaskan bahwa ada satu hadist yang menjelaskan ketika Nabi Muhammad berkhotbah di hadapan umat. Rasulullah SAW bersabda: Hai sekalian manusia ikutilah para ulama, karena ulama itu sebagai damar atau cahaya di dunia dan cahaya di akhirat. Di lain hadist juga dijelaskan bahwa ada tiga perkara yang menerangi bumi dan menerangi ahli langit yaitu:

1) Masjid

2) Rumah ulama bagaikan bintang yang menerangi bumi dan rumah hafidz al-Qur'an akan bercahaya.

Selanjutnya menurut Bapak Solihin beliau merupakan seorang pengajar/guru di sekolah Dasar mengemukakan bahwa yang di sebut dengan ulama merupakan pewaris para Nabi dan tugasnya sama persis seperti Nabi menyampaikan hukum Allah kepada seluruh umat manusia seperti dalam bidang akhlak dan aqidah.

Di jelaskan juga oleh ibu Nurhikmah sebagai Ibu Rumah Tangga dan aktif dalam pengajian jamaah ibu-ibu. Ia menjelaskan bahwa ulama adalah pewaris para Nabi yang meneruskan segala perjuangan Nabi dan membawa kebenaran dan mencegah kedzoliman. Ulama yang mampu memisahkan yang benar dan mana yang salah. Ulama menjadi panutan semua umat manusia untuk menuju jalan yang dikehendaki Allah SWT. Ulama adalah pejuang yang rela berkorban jiwa maupun tenaga dan waktunya hanya digunakan demi keselamatan umatnya supaya terhindar dari tipu daya dunia. Karena jasanya ulama, seseorang akan memperoleh pengetahuan mengenai arti dari sebuah kehidupan. Dari ulama kita bisa mengetahui ilmu agama yang berisikan tentang larangan dan kewajiban.

Ulama yang selalu mengajari mana yang benar mana dan yang salah. Ulama adalah figure dan menjadi cerminan hidup ini dalam sikap serta tingkah laku bahkan apa yang menjadi tutur katanya merupakan sebagai panutan untuk masyarakat.

Menurut Ibu Erod ia mengungkapkan pemahamannya tentang Ulama, bahwa ulama seseorang yang mengerti hukum Islam yang dapat membimbing masyarakat dalam kehidupan. Ia juga menjelaskan keberadaan 
Ulama di Pedesaan sangat penting karena ulama sebagai seseorang yang dapat memberikan pengajaran keagamaan secara mendalam.

Selanjutnya mengenai ulama menurut Bapak Gunawan ulama tokoh yang memiliki tugas menyampaikan apa yang disampaikan oleh Nabi dengan tujuan agar masyarakat mengetahui dan memahami. Menurut Anisa ayu ia seorang siswi Aliyyah menjelaskan bahwa ulama orang yang mengerti ilmu agama yang kedudukannya lebih mulia dan sangat penting bagi dunia. Ulama sendiri adalah seseorang yang dekat dengan Allah yang memiliki akhlak yang mulia.

Menurut analisis penulis, bahwasanya di masyarakat pedesaan memiliki pemahaman yang lebih mendalam tentang ulama. Ulama bukan hanya sekedar orang yang memahami ilmu keagamaan sebagaimana yang di ungkapkan oleh Syekh Nawawi Al-Bantani, yakni bahwa ulama adalah sosok yang paham mengenai hukum syariah saja, tetapi ulama dalam pemahaman masyarakat pedesaan orang yang memiliki ilmu agama sekaligus menjadi panutan atau figur masyarakat pedesaan dalam kehidupan keseharian mereka. Dalam hal ini Ibnu Qayyim Al-Jauziyah menyebut, bahwa terdapat peran ulama dalam ranah sosiologis, yakni sebagai figur otoritatif dalam hubungan internal umat Islam. Dengan fungsi itulah ulama karenanya selalu tampil sebagai sosok yang sangat berperan bagi umat di berbagai ranah. Ranah tersebut ialah sejarah, politik, sosial-kultural dan pendidikan.

\section{b. Peran Ulama Menurut Masyarakat Pedesaan}

Menurut H. Saefullah bahwa peran ulama dalam masyarakat adalah seorang yang dapat mencegah kemungkaran serta menyampaikan kebaikan terhadap umatnya sehingga bisa membawa umat ke jalan yang benar. Selain itu peran ulama juga sebagai pengajar dari para santri dan mengembangkan syariat keagamaan baik di Desa maupun di tingkat Kecamatan, supaya para ulama bisa bersatu untuk membangun Islam. Selain itu menurut $\mathrm{H}$. Saefulloh ulama di pedesaan memiliki tempat dan fungsi sosial yang sangat penting karena menurutnya, ulama merupakan tokoh yang paling penting di masyarakat. Masyarakat bisa mengetahui segala hal baik tentang masalah rumah tangga, ibadah dan bagaimana cara bertani supaya mendapatkan hasil yang baik karena adanya ilmu, dan ilmu itu datangnya dari para ulama. Karena ulama bisa mengetahui apa saja yang harus dilakukan baik buruknya ulama yang dapat mengetahui.

Menurut H. Maman-yang merupakan tokoh/ sesepuh di Masyarakat Desa Cibitung-ulama memiliki peran yaitu membawa orang-orang muslim 
ke jalan yang dikehendaki Allah SWT. Beliau menjelaskan seandainya di dunia ini tidak ada ulama maka manusia mungkin akan bodoh, karena ulama sebagai penerang dan pemberi petunjuk ke jalan yang Allah Ridhoi. ulama merupakan tokoh yang paling penting dan utama, tidak hanya di desa di kota Mekkah pun ulama berada dalam posisi pertama. Karena menurut $\mathrm{H}$. Maman bumi ini bisa berdiri kokoh karena adanya empat golongan diantaranya:

1) Karena ilmunya para alim ulama

2) Adilnya para Pemerintah

3) Kasih sayang orang kaya raya

4) Dan doanya orang faqir.

Menurut H. Maman ia mengatakan kalau ulama tidak bergerak maka pemerintah pun akan mengalami ketidakadilan seperti halnya korupsi. Maka dari itu ulama sangat penting peranannya di masyarakat. Untuk mempertahankan bagaimana peran ulama di masyarakat Pedesaan maka masyarakat harus bisa menjaga sikap baik moral maupun mentalnya.

Selanjutnya menurut Bapak Sholihin ia menjelaskan bahwa peran ulama di Indonesia memiliki tugas bukan hanya dalam bidang agama saja tetapi di semua aspek kehidupan baik agama, sosial dan ekonomi ulama berperan aktif, seperti halnya Nabi selain mempunyai Tugas untuk menyebarkan syariat Islam tetapi beliaupun sebagai kepala Negara. Seperti halnya K.H. Hasyim asy'ari beliaupun ialah sosok ulama yang ikut serta memperjuangkan kemerdekaan Indonesia seperti Muhamadiyyah dan NU yang anggota-anggotanya ulama yang aktif dalam pemerintahan. Sehingga ulama tidak hanya di tugaskan untuk mencegah perbuatan yang keji dan munkar, ulama juga berperan aktif di dalam pemerintahan.

Selanjutnya, Bapak Sholihin mengatakan bahwa ulama yang ada di daerah pedesaan memiliki peranan yang sangat penting dan sangat di butuhkan keberadaannya oleh masyarakat. Karena masyarakat Pedesaan ketika mempunyai masalah baik masalah sekecil apapun pasti mendatangi para ulama. Karena keprcayaan nya sangat tinggi kepada ulama setempat. Menurutnya di Masyarakat jangankan masalah besar, permasalahan seperti mau menanam padi, urusan keluarga adanya perceraian sampai ke permasalahan kenakalan remaja pasti mendatangi ulama. Ini menggambarkan bahwa ulama yang ada di Pedesaan memiliki posisi yang paling tinggi dalam berperan di dalam berbagai hal. 
Menurut Bapak Sholihin bahwasanya ulama di pedesaan kebanyakan hanya menempuh perjalanan pendidikan di pesantren dan jarang yang menempuh pendidikan umum, tetapi dalam proses pengajarannya sangat mempengaruhi dan dianggap penting oleh para santri dan masyarakat. Seperti halnya ketika ulama mengajar di sebuah pesantren atau majlis-majlis pengajian tidak ada satupun para santrinya berani berkata. Berbeda di tempat-tempat seperti perkuliahan terkadang ada murid atau mahasiswa yang berani melawan pembicaraan seorang Dosen atau pengajar. Dan ini membuktikan bahwa ulama dalam menanamkan rasa hormat atau sopan santu lebih berhasil dan lebih di terima oleh para muridnya. Dan di masyarakat pada dasarnya lebih menghargai anak yang hasil dari pendidikan pesantren dari pada pendidikan umum.

Di dalam masyarakat pedesaan menurut Bapak Sholihin bahwa ulama memiliki peranan yang sangat penting, ketika masyarakat mempunyai permasalahan selalu berpusat satu pintu mendatangi para ulama sebelum masyarakat aparat pemerintahan. Sebab ulama di pedesaaan merupakan tokoh yang berpegang teguh terhadap aturan Allah dan patuh terhadap pemimpinnya. ulama pada dasarnya tidak menyukai hal-hal yang dapat memecah belahkan golongan tidak ada kata Islam anti NKRI, malah sebaliknya NKRI berasal dari pokok pondasi Islam. Bisa di buktikan dengan adanya makam para pahlawan di Kali Bata berapa banyak Islam yang menjadi pejuang kemerdekaan. Islam cinta terhadap kemerdekaan mendukung segala aspek dalam pemerintahan malah banyak orang yang memahami agama menjadi pemimpin di pemerintahan dan masuk dalam keanggotaan di DPR.

Selain itu Bapak sholihin menjelaskan para ulama di Pedesaan berjuang tidak mengharapkan imbalan. Berbeda dengan para pegawai negeri yang ketika gajinya belum turun atau sama sekali tidak keluar pasti melakukan demonstrasi. Berbeda dengan para ulama yang memiliki tugas membimbing masyarakat sampai kepada anak-anak nya tetapi mereka tidak mengharapkan imbalan sama sekali, akan tetapi mereka tetap berjuang untuk menjalankan sebuah misi atau tugas dari Allah SWT. Disamping itu ulama mempunyai tujuan supaya hidupnmya bisa bermanfaat bagi yang lain.

Mengenai ulama sebagai tokoh yang paling penting di masyarakat Pedesaan, Bapak Sholihin menjelaskan bahwa dilatarbelakangi karena sebuah kepercayaan. ulama memiliki kepribadian yang taat dan patuh kepada perintah Allah. Sehingga menjadikan masyarakat berlabuh kepada para ulama, dank arena kepercayaan masyarakat sangat tinggi kepada ulama terkadang masyarakatpun tidak merasa keberatan apabila memberi bantuan 
misalnya membantu membereskan temppat tinggal ulama. Masyarakat bersedia merenovasi dan memberikan bantuan kepada ulama tanpa dimintai dulu. Mereka secara ikhlas membantu meringankan beban para ulama.

Untuk mempertahankan peran ulama di masyarakat pedesaan menurut Bapak Sholihin salah satunya dengan memasukan anak-anaknya ke dalam sebuah pesantren, dengan tujuan supaya ulama yang memiliki peran di masyarakat memiliki kelangsungan generasi untuk masa depan. Selanjutnyan menurut Ibu Nurhikamah beliau menjelaskan bahwa tugas atau peran ulama di dalam masyarakat sebagai Imam atau pemimpin dalam hal apapun terutama di dalam kegiatan yang menyangkut agama dan ulama merupakan tokoh terdepan di dalam masyarakat. Misalnya saat hari raya Idul Fitri dan Adha hukum dalam melaksanakannya harus di berjamaahkan maka ulama lah yang selalu menjadi imam. Begitu pula dalam berkhutbah memberikan sebuah fatwa-fatwa maka ulama lah yang berperan. Di samping itu ulama mempunyai peran sebagai guru untuk mengajar atau mendidik ilmu agama baik di dalam fiqih ataupun ilmu tauhid, segala hal apapun yang menyangkut agama maka ulama yang berperan aktif untuk mendidik dan mendorong supaya manusia tahu ilmu itu.

Selanjutnya menurut Ibu Nurhikmah seorang ulama juga terkadang bisa menyadarkan seseorang yang hidupnya penuh dengan kegelapan ketidaksadaran dan lewat nasehat dari para ulama melalui doa-doa nya. ulama bisa berperan juga sebagai orang tua di mana ketika anak-anaknya di didik orang tua dari anak tersebut memasrahkan sepenuhnya sebagai pengganti orang tua kandung kepada para ulama. Sehingga ulama mempunya tugas sekaligus sebagai kewajiban untuk mendidik, mengawasi serta melarang dan memberikan ijin atas apa yang anak itu lakukan. Sehingga menurut Ibu Nurhikmah ulama mengemban tugas dan tanggung jawab yang tidak sepele. ulama juga bisa di jadikan sahabat untuk di mintai solusinya oleh masyarakat dari segala keluh kesah yang menimpa diri kita, sehinnga ulama bisa memberikan jawaban tentang apa yang harus kita lakukan untuk kehidupan kita.

Selanjutnya ibu Nurhikmah menjelaskan bahwa di kehidupan pedesaan Ulama selain menjadi tokoh utama yang dilibatkan dalam sebuah kegiatan baik dalam menyangkut keagamaan atau diluar keagamaan. Karena diyakini dengan ketaatannya seorang ulama dalam beribadah insya Allah diyakini oleh kehidupan masyarakat bahwa sosok ulama penuh dengan kejujuran, ketaatan dan disiplin. Selain itu peran ulama tidak hanya dalam bidang agama saja ulama selalu di butuhkan misalnya dalam bidang 
pemerintahan. Karena di dalam pemerintah ketika ada kegiatan untuk mencapai sebuah tujuan pemerintahpun langsung melibatkan para ulama. Dan tidak tanggung-tanggung di pemerintah pedesaan selalu meminta pendapat atau nasehat para ulama karena untuk mencapai sebuah kelancaran.

Selain itu menurut Ibu Nurhikmah ulama di Masyarakat pedesaan cukup di nomor satukan karena mau ada acara apapun orang yang dimintai nasehatnya oleh masyarakat adalah ulama. Terkadang ada sebagian masyarakat untuk mengadakan acara minta kepada ulama untuk menentukan acaranya demi tercapainya kelancaran. Dan setiap acara yang di adakan masyarakat ulama selalu berperan memimpin doa-doa, selain itu ulama sebagai pemberi fatwa atau sebagai pengisi acara ceramah dalam hajatan.

Ulama juga selalu dimintai pertolongan bagi orang-orang yang terkena musibah untuk bisa mendoakan agar bisa melewati musibah tersebut. Begitu juga ketika ada orang yang meninggal yang mengurusi segala keperluan jenajah ulama yang selalu dilibatkan untuk memimpin dalan mensalatkan dan mendoakan yang meninggal. Menurut Ibu Nurhikamah ia menjelaskan bahwa dalam kehidupan pribadinya lebih memilih untuk mengadu kepada ulama demi untuk memperoleh ketenangan jiwa bahkan jika sakit sekalipun tidak sedikitpun masyarakat pedesaan lebih memilih ulama untuk meminta sebuah keberkahan agar terhindar dari penyakit yang diderita ketimbang pergi berobat ke dokter.

Bahkan ia menjelaskan di jaman dahulu melahirkan saja jarang sekali meminta pertolongan medis atau dengan kata lain kerumah sakit. Tetapi masyarakat cukup di rumah saja dengan meminta pertolongan dukun beranak dan tidak lupa melibatkan ulama untuk diminta mendoakan. Selain itu ketika rumah tangga di guncang jarang sekali orang yang mengadu langsung ke pemerintahan atau pengadilan agama, mereka mengalami permasalahan dalam rumah tangga lebih memilih ulama untuk mendapatkan solusinya. Dalam hal lain ketika masyarakat Desa mencari kerja tidak sedikit mereka datang kepada ulama untuk meminta doanya agar mendapatkan pekerjaan yang baik. begitu juga untuk usaha atau berdagang yang kurang lancar maka dengan mendatangi ulama agar mendapatkan solusinya. Menurut Ibu Nurhikmah memang sudah menjadi tradisi dan kepercayaan bahwa setiap permasalahan mendatangi ulama.

Menurut ibu Erod peran Ulama di masyarakat pedesaan diantaranya memberikan pengarahan keagamaan dalam masyarakat, mendidik anak-anak 
di pesantren, selain itu juga ulama di pedesaan sebagai tempat yang dapat memberikan ketenangan jiwa lewat tausiah-tausiah yang di sampaikan. Ulama di pedesaan berdiri sebagai tokoh yang sangat penting dikerenakan memang ulamalah yang di percaya mampu memberikan solusi dalam berbagai masalah, dan tanpa ulama kita tidak tau yang di haramkan dan yang dihalalkan. Untuk itu menurut ibu Erod keberadaan ulama sangat diperlukan maka kegiatan-kegiatan keagmaanpun di setiap kampung sering dilakukan. Ibu Erod pun menjelaskan sebagai masyarakat ia pun sering mengikuti kegiatan yang diselenggarakan oleh ulama, dan ia pun sering membantu kegiatan-kegiatan seperti maulid Nabi, Isro mi'raj dan kegiatan keagamaan yang di adakan di rumah ulama. Karena menurutnya berpasrtisipasi dalam kegiatan yang diadakan oleh ulama dan membantunya merupakan hal yang harus dilakukan selama kita mampu.

Terkadang kita tidak punya harta kita bantu dengan tenaga tanpa harus diminta oleh ulama. Selain itu Ulama menurut Ibu Erod dapat menyelesaikan berbagai persoalan dan merupakan tokoh yang dituakan dalam masyarakat, dan ketika kita mendapat kesusahan rezeki minta doa kepada ulama sering ia lakukan, ketika sedang sakitpun datang kepada ulama karena ulama orang yang dekat dengan Allah dan merupakan sebagai jalan meminta kesembuhan kepada Allah SWT lewat doa ulama.

Selanjutnya menurut Bapak Gunawan ia seorang yang bekerja di daerah perkotaan menjelaskan bawa peran ulama di pedesaan memiliki perbedaan dengan pemahaman peran ulama di perkotaan. Menurutnya masyarakat di pedesaan sangat aktif, ketika mempunyai pengajaran pengetahuan dari ulama mereka mendengarkannya. Sedangkan dalam masyarakat perkotaan, tidak memiliki keaktifan yang signifikan sebagaimana dalam masyarakat desa. Terkadang masyarakat perkotaan memahami ulama sebagai seorang tokoh yang dapat memberikan pemahaman keagamaan, tetapi karena beberapa faktor terkadang masyaraktpun tidak dapat mendatangi langsung ulama ada yang sengaja tidak memerlukan keberadaan ulama karena sifat acuhnya ada juga karena kesibukan lain.

Menurut Bapak Gunawan sendiri ia menjelaskan bahwa di pedesaan mayoritas masyarakatnya masih aktif mengikuti kegiatan-kegiatan keagamaan sedangkan masyarakat perkotaan kenapa masyarakatnya kurang aktif dalam kegiatan keagamaan karena mereka disibukan dengan kegiatan pekerjaannya sehingga tidak ada waktu untuk mengikuti kegiatan keagamaan para ulama. Namun ada sebagian masyarakat perkotaan juga yang aktif dalam kegiatan keagamaan itupun kalau mereka tidak disibukkan dengan pekerjaannya. 
Menurut Bapak Gunawan masyarakat pedesaan menaruh kepercayaan penuh pada ulama karena ulama dipercayai memiliki kapabilitas dalam bicara agama sekaligus sebagai orang yang amat dekat kepada Tuhan, sehingga seringkali masyarakat ketika mendapat permasalahan mendatangi ulama meminta doanya karena ulama merupakan sebagai jalan atau syariat yang ditempuh. Selain itu menurut Bapak Gunawan supaya masyarakat tetap berada dalam kehidupan yang sesuai dengan syariat Islam maka peranan ulama dalam kehidupan sangat dibutuhkan, apalagi di jaman yang serba modern nasehat-nasehat dari ulama perlu dilakukan salah satunya dengan terus dekat dengan ulama sesibuk apapun kita harus meluangkan waktu mengikuti kegiatan-kegiatan keagamaan.

Menurut Anisa ayu ia menjelaskan bahwa peran atau tugas ulama sangatlah penting tidak hanya dikalangan masyarakat dalam dunia pendidikanpun peran ulama sangat dibutuhkan, jika kita hanya mengandalkan guru psikologi misalnya itu tidak akan cukup dan tidak sempurna tanpa peran dari ulama. Di masyarakat pedesaan menurut Anisa ayu menjelaskan peran ulama sangat penting, masyarakat pada umumnya memiliki kebiasaan dalam kehidupannya mengikuti apa yang di arahkan oleh ulama karena kepercayaan terhadap ulama sangatlah kuat. Bahkan Anisa Ayu sendiri menyampaikan terkadang dalam kehidupan seorang murid ketika di suruh oleh guru di sekolah kurang di dengarkan dan terkadang mengabaikan, akan tetapi ketika di suruh oleh kyai atu guru di pesantren lebih cenderung di dengarkan dan ditakuti.

Maka dari itu menurut Anisa Ayu perlu mempertahankan peran ulama dalam kehidupan, salah satunya para pemuda harus terus mengikuti pengajaran-pengajaran dipesantren karena dengan tinggal di pesantren dan di didik oleh ulama kehidupan kita akan terjaga dari hal-hal yang terlarang. Sekolahpun penting karena untuk menunjang kehidupan kita d dunia.

Dari beberapa pendapat yang di sampaikan oleh masyarakat pedesaan mengambarkan bahwa ulama mempunyai peran siginifikan dalam masyarakat. Tidak hanya dalam hal keagamaan seperti memberikan fatwafatwa, menyampaikan tentang yang halal dan haram, Ulama di pedesaan memiliki peran juga di bidang ekonomi dan sosial. Karena menurut masyarakat ulama merupakan tempat yang paling baik untuk dimintai solusi dalam setiap masalah. Seperti halnya masalah ekonomi, ketika seseorang mendapatkan kesulitan dalam berbisnis maka cara yang dilakukan yaitu dengan mendatangi para ulama. Karena ulama diyakini sebagai sosok yang mulia yang dapat memberikan solusi baik berupa nasehat atau doa. Dalam 
hal lain juga diyakini oleh masyarakat bahwa ketika masyarakat mengalami kegagalan dalam bertani, maka ulama merupakan tempat yang paling baik untuk di mintai solusi. Karena diyakini bahwa kegagalan yang di alami ada kaitannya dengan masalah agama yang harus didiskusikan dengan ulama untuk mendapatkan nasehatnya. Keyakinan yang sangat tinggi terhadap para ulama menjadikan posisi aparat pemerintah menjadi nomor dua setelah ulama. Melihat dari fakta tersebut bahwa kepercayaan masyarakat pedesaan terhadap seorang ulama sangatlah tinggi sehingga masyarakat sepenuhnya percaya bahwa ulama merupakan tokoh yang bisa membawa kehidupan mereka ke jalan yang di ridoi Allah. Dari pemahaman yang di jelaskan oleh masyarakat pedesaan mengenai peran atau tugas ulama menurut analisa penulis ada kesesuaian dengan apa yang di jelaskan oleh Qurasih Shihab dalam buku membumikan al-Qur'an menguraikan empat peran penting ulama yang dijadikan sesuai dengan misi kenabian yaitu:

1) Menyampaikan dakwah/tabligh yang merupakan ajaran Nabi sebagaimana firman Allah "Wahai Rasul, sampaikanlah apa yang diturunkan kepadamu dari Tuhanmu ayat ini tercantum dalam Surat Al-Maidah. Maka tugas Rasul untuk masa sekrang ini menjadi tanggung jawab para ulama.

2) Menjelaskan ajaran-ajarannya, karena tugas menyampaikan misi al-Qur'an dan penjelasannya menjadi tanggung jawab ulama, kiai atau cendekiawan muslim yang memiliki kapasitas keilmuan yang lebih tinggi dari yang lain.

3) Menyelesaikan masalah yang ada di masyarakat, sesuai firman Allah, "Dan Allah turunkan bersama mereka al-Kitab dengan besar agar dapat memutuskan perkara yang diperselisihkan manusia." Ayat ini menjelaskan bahwa tugas mendamaikan dan mencarikan penyelesaian terhadap masalah-masalah yang dihadapi masyarakat yaitu para ulama.

4) Memberikan contoh. Hal ini terdapat dalam hadist yang diriwayatkan oleh Aisyah yang berbunyi, bahwa perilaku Nabi adalah praktik al-Qur'an. Sebagaimana ulama yang sudah menjadi panutan masyarakat, maka segala ucapan, gerak-gerik perbuatannya menjadi contoh atau panutan masyarakat. Karenanya ulama harus senantiasa menjaga kehornatan dan wibawanya agar tetap menjadi panutan masyarakat. ${ }^{2}$

\section{c. Manfaat dekat dengan Ulama menurut Masyarakat}

\section{Pedesaan}

\footnotetext{
${ }^{2}$ Dr. Bahrul Ulum, MA, Ulama dan Politik (Yogyakarta: Pustaka Pelajar, 2015, hlm.1415
} 
JAQFI: Jurnal Aqidah dan Filsafat Islam, Vol. 4, No. 1, 2019 | h. 78-104 Paridah Napilah, Ahmad Gibson Albustomi. I p-issn 2541-352x e-issn 2714-9420

Manfaat ketika masyarakat dekat dengan ulama menurut $\mathrm{H}$. Saefulloh seseorang akan mendapatkan kebaikan dalam hidupnya, baik dalam bidang pertanian, ekonomi dan ibadahnya. Karena menuurut nya apabila masyarakat jauh denagn ulama maka ia akan mendapatkan dua hal diantaranya:

1) Masyarakat yang jauh dengan ulama maka dampaknya akan memperoleh pemimpin yang dzolim

2) Masyarakat tidak akan mendapat keberkahan dalam hidupnya.

Di jelaskan juga oleh $\mathrm{H}$. Maman bahwa seorang masyarakat ketika dekat dengan para ulama hatinya tidak akan keras dan akan memiliki hati yang lembut. Selain itu kehidupannya akan di permudah dan di berkahkan. Selain itu menurut Bapak Sholihin ketika masyarakat dekat dengan ulama akan memiliki akhlak yang lebih baik, hatinya akan merasa tenang dan merasa seperti dekat dengan Nabi karena dekat dengan para ulama. Selain itu orang yang dekat dengan ulama akan mendapatkan pahala, bukan hanya sekedar dekat melihatnya pun akan bernilai ibadah. Dari sisi sosial menurut Bapak Sholihin bahwa orang yang dekat dengan ulama akan memperoleh pandangan atau penilaian yang positif dari masyarakat, seperti halnya orang yang dekat dengan penjual parfum walaupun tidak menjual tapi wanginya akan terasa. Menurut Ibu Nurhikmah ia menjelaskan bahwa ketika orang dekat dengan ulama maka akan memperoleh manfaat, yaitu akan memiliki ketenangan hati dan kenyamanan jiwa karena ulama merupakan sosok yang di segani, dihormati tanpa permintaan Dario seorang ulama untuk di hormati. Terkadang ketika kita berhadap-hadapan dengan ulama hati kita akan terasa malu. Bahkan saya akui bahwa ulama merupakan sosok istimewa dan orang tua ke dua setelah ibu bapak kita. Ketika kita ada dalam kehilapan bila dekat dengan ulama maka kita tidak akan terlelap dalam kehilapan itu karena adanya nasehat yang selalu menyertai kiya yaitu dari para ulama. Dan ketika kita selalu mengikuti nasehat beliau, keberkahan akan selalu muncul menyertai hidup kita. Selain itu ketika kita berkegiatan usaha atau berbisnis dan kita tidak terlepas dari ansehat ulama maka kita akan mendapatkan keberkahan yang tidak terhingga dan ketika kita punya ilmu atas dasar tuntunan beliau ingsya Allah hidup kita di berkahi lebih mudah untuyk menjalani segala kehidupan apabila ddekat dengan ulama.

Menurut ibu Erod sendiri ia menjelaskan ketika dekat dengan ulama maka segala sesuatunya akan berkah akan mendapat kemudahan dalam memahami permasalahan. Selain itu dekat dengan ulama dapat menambah 
pengetahuan kita tentang keagamaan. Selanjutnya menurut Bapak Gunawan ia menjelaskan manfaat dekat dengan ulama maka kita akan mendapatkan perasaan tenang dan hiduppun ada tujuannya.

Menurut Anisa Ayu ia menjelaskan bahwa ketika dekat dengan ulama ilmu menjadi bertambah, akhlak akan terjaga dan mendapatkan pemahaman ilmu agama yang mendalam. Sedangkan ketika jauh dari ulama hidup kita tidak akan terarah dan tidak akan mengetahui pemahaman keagamaan secara mendalam.

Menurut analisa penulis tentang manfaat yang diperoleh masyarakat pedesaan dengan ulama. Masyarakt percaya bahwa akan dapat manfaat yang besar ketika seseorang dekat dengan ulama. Kemudahan dan keberkahan akan mereka peroleh dalam kehidupannya. Selain itu seseorang akan memiliki hati yang tenang ketika dekat dengan ulama. Karena ulama merupakan sosok yang diyakini sebagai tokoh yang berpengaruh untuk kehidupan masyarakat pedesaan. Tidak hanya menambah wawasan keagamaan yang diperoleh ketika dekat dengan ulama, kemudahan dalam berbisnis, kelancara dalam menjalani kegiatan sehari-hari akan diperolehnya. Ulama di yakini seorang manusia yang mulia dan berpengaruh dalam kehidupan masyarakat desa, doa-doa nya sangat di harapkan keputusan nya diyakini sebagai tindakan yang benar yang akan membawa keberkahan bagi kehidupan.

Kepercayaan akan keberkahan yang diyakini oleh masyarakat pedesaan ketika dekat dengan ulama di dasarkan bahwa ulama merupakan orang yang berilmu, dan apa yang diperintahkannya merupakan kebaikan dan harus di ikuti oleh masyarakat. Selain itu penulis juga menemukan bahwa ketika masyarakat jauh dengan ulama maka ia tidak akan mendapatkan keberkahan dalam hidupnya. berkah disini diartikan sebagai mendapat kelancaran dan kemaslahatan dalam hidupnya. Sedangkan ketika jauh dari para ulama maka seseorang di ibaratkan seperti berada dalam kegelapan.

Keyakinan dan kepercayaan yang kuat masyarakat pedesaan dilatarbelakangi oleh beberapa hal seperti yang di jelaskan dalam buku Hiroko Horikoshi yaitu:

1) Mereka memperoleh pengetahuan ibadah, karena amal baik ulama.

2) Ulama adalah alat untuk memperoleh kebajikan, karena mereka menawarkan program agama dan meyediakan bagi orang-orang Desa fasilitas yang diperlukan untuk menjalankan kegiatan keagamaan. 
JAQFI: Jurnal Aqidah dan Filsafat Islam, Vol. 4, No. 1, 2019 | h. 78-104 Paridah Napilah, Ahmad Gibson Albustomi. I p-issn 2541-352x e-issn 2714-9420

3) Karena ulama sebagai perantara antara Tuhan dan umat. Mereka memberikan saran-saran dan bimbingan agama terhadap kesulitankesulitan, menyuruh mereka membaca surat tertentu dari al-Qur'an agar mendapat rahmat Tuhan dengan cepat melalui permohonan langsung, meskipun ulama tidak menawarkan agar berdoa melalui dirinya. ${ }^{3}$

\section{Pemahaman Teologis Masyarakat Perkotaan tentang Peran}

\section{Ulama}

\section{a. Pemahaman masyarakat tentang ulama}

Menurut Bapak Surya seorang wiraswasta beliau menjelaskan bahwa yang di sebut dengan ulama merupakaan penerus wali-wali yang menjadi tolak ukur atau panutan masyarakat dalam kehidupan beragama dan tokoh yang di tua kan dalam kehidupan sehari-hari. Bapak Surya menjelaskan bahwa ulama memiliki ciri-ciri yaitu memiliki ilmu keagamaan dan memeproleh pendidikan agama secara khusus. Selain itu gelar ulama tidak hanya di berikan oleh masyarakat biasa, pemerintahpun memberikan gelar khusus kepada para ulama. Sedangkan menurut Ustadz Muhamad beliau merupakan seorang Ustadz sekaligus pengajar di Daarut Tauhid, beliau menjelaskan bahwa ulama secara bahasa berasal dari kata 'Alim' yaitu diartikan sebagai seseorang yang mengetahui atau mengenal maka di sebut dengan ulama. Sedangkan secara istilah ulama merupakan seseorang yang benar-benar mengenal Allah. Ustazd Muhamad pun jelaskan bahwa seseorang bisa di sebut ulama karena ia mengetahui serta mengenal ilmu dan menyampaikannya kepada masyarakat.

Ulama menurut Ustadz Muhamad memiliki beberapa nama khusunya di Indonesia. Seperti halnya di Aceh ulama biasa di sebut dengan Teungku sedangkan di Jawa biasa di panggil Kyai atau Ajeungan. Selain itu Ustadz bila diartikan secara bahasa memiliki makna mendidik atau mengajar. Menurut Ustadz Muhamad beliau menjelaskan bahwa di Arab pun yang disebut dengan Ustadz ialah tokoh agama yang memiliki pengaruh dalam masyarakat sedangkan di Indonesia Ustadz sendiri sebagai pengajar dalam bidang ke agamaan saja namun dalam konteks masih bisa di sebut ulama.

Selanjutnya menuurt Ibu Nunung yang kesehariannya sebagai Ibu rumah tangga ia menjelaskan bahwa ulama merupakan orang yang di hargai dan di hormati sebagai guru spiritual dan orang yang pintar yang memahami

\footnotetext{
${ }^{3}$ Dr. Hiroko Horikoshi, Kyai dan Perubahan Sosial, Jakarta, Perhimpunan Pengembangan Pesantren dan Masyarakat, 1987. hlm. 101
} 
atau mendalami pengetahuan agama. Ia pun menjelaskan bahwa ulama memiliki ciri-ciri khusus di dalam masyarakat.

1) Memiliki sikap dan kepribadian yang baik untuk memberikan contoh kepada masyarakat dan lingkungan sekitar.

2) Memahami dan mengamalkan ilmu agama Islam.

Bagi Bapak Herman koswara ia merupakan seorang pegawai swasta, mengatakan bahwa yang di sebut dengan ulama orang yang mempunyai pengaruh besar dalam masyarakat perkotaan terutama di dalam ilmu ke agamaan. Beliau juga menjelaskan bahwa yang di sebut ulama mempunyai ciri-ciri khusus yaitu:

1) Seorang yang mengerti ilmu ke agamaan.

2) Mampu menjadi penengah di dalam masyarakat apabila ada permasalahan.

3) Seorang ulama biasa menjadi Imam baik dalam shalat Jum'at ataupun menjadi Imam dalam perayaan hari besar umat Islam.

Selanjutnya menurut salah satu pelajar Radiah Fitriani ia menjelaskan bahwa ulama adalah pemimpin agama yang tugasnya membimbing masyarakat sebagai pengganti para wali. Ulama seseorang yang membimbing serta mengarahkan masyarakat sesuai dengan syariat Islam.

Selanjutnya menurut Bapak Wawan ia seorang pegawai swasta menjelaskan bahwa ulama seseorang yang diyakini memiliki pengetahuan agama secara mendalam. Dimana ulama merupakan pemimpin-pemimpin dalam keagamaan. Menurut Bapak Dani Ramdhani seorang petugas kebersihan ia menjelaskan bahwa ulama merupakan pemuka agama yang pandai dalam agama Islam untuk di sampaikan kepada masyarakat. Menurut analisa penulis, bahwa masyarakat perkotaan dalam pemahamannya mengenai ulama tidak jauh berbeda dengan pemahaman masyarakat pedesaan. Yaitu bahwa seorang ulama merupakan pewarais para Nabi yang mana dalam hadist dijelaskan juga "al ulama waratsatul anbiya" ulama adalah pewaris Nabi-Nabi yang mana memiliki tugas menyampaikan ilmu agama kepada masyarakat. Masyarakat perkotaan memahami pemahamannya tentang ulama hanya sebagai seorang yang memiliki pemahaman keagamaan yang mampu menjadi contoh atau figure masyarakat dalam menjalani kehidupan beragama.

\section{b. Peran ulama menurut Masyarakat perkotaan}


Menurut Bapak Surya ia menjelaskan bahwa peran ulama dalam masyarakat tentunya sangat penting karena sebagai tokoh yang memberikan masukan atau nasehat dalam bidang agama. Karena ulama yang memberikan bagaimana kita menjalani kehidupan beragama yang baik dan ulama merupakan tokoh panutan masyarakat.

Bapak Surya dalam hal ini menjelaskan alasan kenapa ulama bisa menjadi tokoh yang penting dalam masyarakat karena ulama merupakan sosok yang memiliki pendidikan keagamaan yang sangat tinggi sehingga mampu memeberikan contoh yang baik dan selalu mengajak masyarakat ke arah yang lebih baik. Bapak Surya juga menjelaskan bahwa upaya masyarakat agar keberadaan ulama tetap ada dalam lingkungan masyarakat seiring perkembangan jaman, masyarakat mesti terus mendekatkan diri kepada ulama. Karena ulama sangat penting dalam masyarakat, di samping adanya pemerintah, dalam hal keagamaan ulamalah yang dibutuhkan untuk menjalani kehidupan sehari-hari. Tetapi dalam ruang lingkup yang lebih luas masyarakatpun wajib pada aturan yang ditetapkan oleh pemerintah.

Untuk mempertahankan keberadaan ulama dalam lingkungan masyarakat menurut Bapak Surya, kita mesti mengadakan pendidikan keagamaan di masjid-masjid seperti mengadakan pengajian untuk orang dewasa hingga anak-anak. Karena bisa jadi ketika ulama tidak ada kehidupanpun akan terasa hambar.

Selanjutnya menurut Bapak Surya beliau mengatakan bahwa permasalahan yang biasa ia bawa penyelesaiannya kepada ulama yaitu masalah-masalah tentang keagamaan. Karena sebagai orang awam tidak mungkin kita mereka-reka sesuatu permasalahan tanpa mendatangi sumbernya yaitu ulama. Seperti masalah ahli waris kalau kita tidak tahu cara penyelesaiannya maka kita harus mendatangi ulama. Maka dari itu permasalahan-permasalahan yang di bawa ke ulama merupakan masalahmasalah yang ada kaitannya denga keagamaan. Kalaupun ada masalah sosial seperti adanya pertikaian itu datangnya ke aparat pemerintah. Karena dalam kehidupan di masyarakat perkotaan sudah ada aturan baku yang di tetapkan oleh pemerintah yang harus di ikuti oleh masyarakat.

Bapak Surya juga menjelaskan ulama tempat untuk dimintai doa, sekalipun ada orang yang sakit boleh minta doa kepada para ulama. Di samping meminta doa kepada para ulama tetap saja kita harus mendatangi Dokter untuk mengobati penyakit yang sedang di alami. Ulama juga bisa mengobati penyakit, namun penyakit yang di luar nalar kita yang tidak dapat di mengerti oleh akal pikiran seperti orang yang kesurupan. Selanjutnya 
menurut Bapak Muhamad ia menjelaskan bahwa peran atau tugas ulama yaitu menyampaikan ilmu supaya masyarakat taqwa kepada Allah. Sebagai ulama ia mempunya peran untuk menjelaskan hukum-hukum baik itu hukum aqidah, ibadah dan sebagainya. Ulama merupakan tempat di mintai solusi dalam masalah khususnya masalah kegamaan. Karena ulama sendiri memiliki ciri khusus untuk mengajak berbuat kebaikan dan segala yang dilarang oleh Allah SWT.

Bapak Muhamad menjelaskan bahwa di masyarakat perkotaan masyaraknyapun bisa dikatakan dekat dengan para ulama. Karena di dalam lingkungan masyarakat sering di adakan acara-acara keagamaan yang melibatkan ulama seperti adanya kegiatan majlis ta'lim. Selain itu menurut Bapak Muhamad di dalam masyarakt perkotaan masalah-masalah yang sering masyarakat melakukan konsultasi dengan ulama yaitu masalah shering tentang bagaimana kehidupan yang mesti dijalani karena ulama merupakan panutan atau contoh yang harus di ikuti karena segala perkataannya dapat dipercaya. Di dalam masyaraat perkotaan kedekatannya dengan ulama bisa di bilang sangat dekat, namun perlu di garis bawahi kedekatanya itu hanya dalam masalah-masalah keagamaan. Di jelaskan juga latar belakang ulama sebagai tokoh yang di hormati oleh masyarakat perkotaan, karena ulama merupakan pewaris para Nabi. Sebagai mana Rasul dulu sering di datangi oleh masyarakat ulama pun sama tugas nya seperti para Nabi.

Bapak Muhamad menjelaskan sekalipun ada masalah yang penyelesaiannya dengan mendatangi ulama maka masalah tersebut harus yang bersangkutan dengan keagamaan. Karena masalah seperti kenakalan remaja yang melanggar aturan maka yang harus di datangi aparat pemerintah setempat, dan misalnya ada yang sakit harus mendatangi dokter yang berkaitan dengan penyakit tersebut. Masyarakat perkotaan cukup memahami ketika mereka memiliki seorang anak yang melakukan kesalahan cenderung lebih memilih ahlinya seperti sikolog tidak ke ulama, paling kalaupun ada yang mendatangi ulama hanya untuk meminta solusi dalam masalah keagamaan dan ulama sendiri biasanya memberikan nasehat langsung ke pada orang tuanya karena bisa jadi masalah tersebut ada kaitannya dengan orang tuanya. Maka dari itu menurut ustadz Muhamad supaya anatara masyarakat dan ulama bisa dekat masyarakat dan ulama harus mengoptimalkan kegiatan-kegiatan keagamaan, karena disitulah salah satu cara supaya masyarakat dan ulama bisa bersatu untuk membangun kehidupan yang sesuai ajaran Islam dengan adanya tausiah-tausiah. 
Menurut Ibu Nunung peran ulama di Masyarakat perkotaan diantaranya sebagai penasehat dalam bidang keagamaan, mengajak masyarakat untuk mengikuti pengajian, selain itu mendidik generasi yang muda dan sebagai tokoh masyarakat yang di hargai dan di hormati. Selain itu alasnnya kenapa ulama bisa menjadi tokoh yang paling penting dalam masyarakat menurut Ibu Nunung sendiri, karena pemahaman keagamaan masyarakat perkotaan masih harus banyak bimbingan keagamaan dari para ulama. Karena sebagai umat Islam kita harus memiliki pemahaman yang baik dalam masalah agama, dan para Ulamalah yang membimbing kita untuk paham dalam masalah keagamaan.

Selain itu menurut Ibu Nunung untuk mempertahankan peran ulama dan supaya ulama tetap ada dalam kehidupan kita maka sebagai masyarakat kita harus mendirikan masjid-masjid untuk kegiatan keagamaan yang melibatkan tokoh ulama sebagai pemimpinnya. Di samping itu di adakannya acara tausiah-tausiah untuk menambah wawasan keagamaan.

Ibu Nunung juga menjelaskan bahwa masalah yang biasa ia selesaikan dengan para ulama yaitu meminta pencerahan tentang kehidupan yang menyangkut dengan keagamaan. Adapun masalah seperti kena sakit maka tidak apa-apa minta doa dari ulama, di samping doa dari ulama kita juga harus mendatangi dokter untuk mengobati penyakit tersebut.

Menurut Bapak Herman Koswara ia menjelaskan bahwa ulama mempunyai tugas khusus di dalam masyarakat diantaranya peran ulama memberikan pemahaman keagamaan kepada masyarakat. Selain itu mempimpin perayaan hari besar umat Islam, memberikan tausiah-tausiah dalam acara keagamaan.

Bapak Herman Koswara menyampaikan juga bahwa seorang ulama bisa menjadi tokoh yang di segani oleh masyarakat perkotaan dikarenakan beliau mampu memberikan contoh yang baik dan sebagai panutan dalam masyarakat. Karena seorang ulama berbeda dengan masyarakat yang lainnya ia mempunyai pengetahuan agama yang lebih di bandingkan masyarakat lainnya.

Maka dari itu menurut Bapak Herman koswara untuk mempertahankan peran ulama maka masyarakat dengan ulama harus bersama-sama mengadakan kegiatan pyang menyangkut keagamaan seperti tablig akbar, mendirikan masjid dan memakmurkannya, mengadakan tempat pendidikan keagamaan.

Selain itu masyarakat perkotaan menurut Bapak Koswara ketika memiliki permasalahan-permasalahan yang menyangkut keagamaan, seperti 
masalah hak waris, masalah talak lebih di tekankan mendatangi ulama. Namun apabila masalah yang di hadapi seperti masalah sosial seperti kerusuhan biasanya mendatangi aparat pemerintah setempat. Adapun ada orang yang sakit masyarakat biasanya langsung datang kepada dokter yang bisa menangani penyakitnya.

Menurut Radiah Fitriani ia menjelaskan ulama memiliki peran dan tugas dalam masyarakat yaitu mengenalkan syariat agama Islam sesuai yang telah ditentukan dengan cara damai tanpa memusuhi. Ulama menurutnya merupakan tokoh yang paling penting dalam masyarakat, karena ulama tokoh yang mengenalkan Islam setelah para wali, makanya masyarakat juga menganggap bahwa ulama sebagai dasar yang mengenalkan mereka terhadap syariat Islam. Ulama di perkotaan betugas untuk membimbing masyarakat dalam bidang keagamaan dan mendidik para santrinya. Radiah sendiri ia menjelaskan bahwa ulama merupakan menjelaskan pemahamanpemahaman mengenai hal yang berkaitan dengan keakhiratan, sehingga dengan adanya ulama dapat memberikan atau mengarahkan kita untuk mencapai kesuksesan di akhirat nanti. Maka dari itu bisa di asumsikan tanpa adanya seorang ulama disuatu kota maka dapat menimbulkan bermacammacam kemaksiatan dan termasuk kepada salah satu ciri-ciri terjadinya kiamat.

Radiah Fitrianipun menjelaskan bahwa ketika di dalam tahap belajarpun ia lebih patuh terhadap guru ngaji atau ustadz yang membimbingnya karena menurutnya guru ngaji memberikan jalan kesuksesan menuju ke akhirat, karena akhiratlah hidup yang sesungguhnya abadi, di duniapun tanpa adanya ilmu agama maka akan tersesat dan lupa kepada Allah SWT.

Menurut Bapak Wawan ia menjelaskan ulama dalam masyarakat perkotaan mempunyai peran hanya dalam kaitannya dengan masalah agama. Karena menurutnya, masyarakat perkotaan memandang ulama seseorang yang dapat memimpin pengajian yang sering di adakan di mesjid-mesjid. Adapun masalah-masalah yang dialami oleh masyarakat seperti terkena musibah Bapak Wawan sendiri berpendapat lebih baik langsung berserah diri kepada Allah. Karena apa yang ia alami masalah- masalah hidup ia memilih untuk merundingkan bersama keluarga tanpa harus memilih mencoba menyelesaikan dengan pihak lain seperti ulama. Hal semacam ini biasa ia lakukan dengan kelurga lainnya yang berada di daerah perkotaan dan menurut Bapak Wawan sendiri itu sudah menjadi budaya masyarakat perkotaan yang mana mempunyai karakteristik individualis serta berpikir 
logis. Berbeda dengan masyarakat pedesaan yang mana menurut Bapak Wawan sendiri masyarakat perkotaan budaya dalam kehidupan itu ia meyakini bahwa segala sesuatu permasalahan hidup mereka sering bertanya ke orang-orang yang dianggap mampu memberikan solusi seperti ulama. Karena masyarakat pedesaan memang sudah memiliki keyakinan yang kuat terhadap para ulama.

Bapak Wawan sendiri mengatakan ia mempunyai kerabat yang dari daerah pedesaan yang mana ketika mendapat permasalahan selalu menanyakan ke orang-orang yang di anggap mampu, dan ketika salah satu keluarganya yang dari kota pindah ke daerah iapun mengikuti budaya di daerah tersebut yaitu mempercayai bahwa meminta pertolongan atau solusi kepada orang yang dianggap mampu seperti ustadz. Namun menurut Bapak Wawan sendiri tidak masalah hal tersebut dilakukan karena setiap orang berbeda dan mempunyai keyakinan dalam kehidupannya.

Selanjutnya, menurut Bapak Wawan keberadaan ulama atau ustadz sangat diperlukan untuk mengajarkan keagamaan yang mendalam mendidik anak-anak ngaji di masjid, karena biasanya anak-anak lebih cepat belajar pengetahuan agama dengan ulama di masjid-masjid daripada dirumah sendiri. Maka untuk itu supaya peran ulama tidak bergeser keberadaannya agar tetap membimbing masyarakat dalam bidang agama, maka kegiatankegiatan keagamaan di setiap masjid harus sering dilakukan.

Selanjutnya menurut Bapak Dani Ramdani ia menjelaskan peran ulama dalam kehidupan merupakan seorang yang bisa menjaga kemurnian dan kesucian Islam, ulama sebagai pemersatu umat juga dalam kaitannya dengan agama. Karena menurut Bapak Dani Ramdani ulama ialah orang yang mampu memberi pemahaman keislaman yang akan dipraktikan dalam kehidupan sehari-hari, contohnya adalah shalat.

Menurut Bapak Dani dalam pengalamnnya sehari-hari dilihat dari lingkungan ia tinggal masyarakat perkotaan memiliki perbedaan dalam menyikapi peran ulama, menurutnya ulama dalam masyarakat perkotaan tidak terlalu dekat dengan ulama, termasuk saya sendiri. Tapi alasannya bukan karena tak ingin, namun karena keterbatasan waktu yang dimiliki untuk melakukan kegiatan-kegiatan yang berkaitan dengan ulama. Terkadang menurut Bapak Dani bisa bertemu dengan ulama ketika khutbah di hari jumat, karena hari biasa ia habiskan di tempat pekerjaannya. Orang sibuk bekerja sulit untuk berdiskusi tentang agama, apalagi sengaja mendatangi ulama karena ada faktor lain yang lebih mendesak. 
Dari pemahaman masyarakat perkotaan mengenai peran ulama di temukan bahwa masyarakat memandang bahwa peran atau tugas ulama hanya sebagai figur dalam kehidupan beragama. Ulama sebagai tokoh yang mampu menyelesaikan permasalahan yang di hadapi oleh masyarakat dalam bidang keagamaan. Karena masyarakat perkotaan memandang tidak semua permasalan kehidupan seperti ekonomi ataupun masalah sosial bisa di selesaikan dengan ulama. Masyarakat perkotaan cenderung berpikir rasional yang mana menempatkan permasalahan seperti adanya orang sakit mereka mempercayai dokter sebagai solusi untuk menyembuhkan penyakit yang dideritanya dan ketika ada permasalahan yang terjadi di masyarakat untuk penyelesaiannya dilakukan di aparat pemerintahan setempat.

\section{c. Manfaat dekat dengan Ulama Menurut Masyarakat Perkotaan}

Menurut Bapak Surya ada manfaat yang dirasakan ketika masyarakat dekat dengan ulama, diantaranya kita bisa memahami hukum-hukum yang telah di tetapkan Allah kepada hambanya, karena ulama memiliki pemahaman tentang aturan-aturan agama. Maka dekat dengan ulama kita sebagai masyarakat yang awam bisa langsung menanyakan hal-hal yang tidak di ketahui kepada ulama.

Selanjutnya menurut Ustazd Muhamad beliau menjelaskan bahwa manfaat yang di rasakan ketika dekat ulama mereka bisa lebih memahami pemahaman keagamaan sehingga banyak sekali masyarakat yang memakmurkan masjid-masjid dengan mengadakan kegiatan-kegiatan keagamaan. Di samping itu dalam bidang ekonomi seperti berdagang ulama juga memiliki pengaruh terhadapa masyarakat. Yang mana masyarakat bisa mengetahui bagaimana caranya berdagang yang baik yang di anjurkan oleh agama dan masyarakat bisa menanyakan langsung kepada ulama.

Menurut Ibu Nunung beliau menjelaskan bahwa manfaat yang di rasakan ketika dekat dengan ulama kita akan merasa tenang, damai dan mudah untuk mendapatkan penjelasan-penjelasan tentang permasalahan yang di hadapi, baik itu masalah agama maupun masalah yang berkenaan dengan kehidupan sosial. Ulama bisa menjadi tempat yang baik untuk di jadikan tempat meminta pendapat dalam kehidupan.

Menurut Bapak Herman Koswara beliau menjelaskan bahwa manfaat dekat dengan ulama ia akan mudah bertukar pikiran dan mendapatkan pemahaman keagamaan dan bisa ikut serta dalam kegiatan-kegiatan keagamaan. Menurut Radiah Fitrian banyak yang akan di dapatkan ketika 
kita dekat dengan ulama, semakin dekat dengan ulama maka semakin dekat pula hubunganmu dengan sang Kholik, sehingga ulama memberikan manfaat yang penuh dalam mengatasi persoalan akhirat, dan begitupun menentramkan hati bagi para pendengar nasehat beliau.

Menururut Bapak Wawan banyak hal yang diperoleh ketika dekat dengan ulama salah satunya menambah pengetahuan agama, karena sebagai masyarakat biasa kita tidak paham dengan syariat Islam maka dengan dengan ulama atau ustadz kita bisa memperoleh pemahaman keagamaan. Manfaat dekat dengan ulama menurut Bapak Dani tentu orang tersebut akan mengetahui kebenaran-kebenaran ajaran Islam, tidak akan salah dalam memahami Islam karena dekat dengan ulama dapat bertanya secara langsung. Masyarakat perkotaan memahami bahwa dekat dengan ulama akan mempermudah dalam menanyakan berbagai hal masalah yang berkaitan dengan keagamaan. orang yang dekat dengan ulama akan mendapatkan pemahaman keagamaan yang lebih dalam, karena berteman dengan ulama akan secara tidak langsung akan menjadikan mereka giat dalam menjalankan kegiatan-kegiatan yang di adakan seperti pengajian.

\section{Analisa Perbandingan.}

Dari hasil penelitian ditemukan bahwa adanya perbedaan pemahaman antara masyarakat pedesaan dengan masyarakat perkotaan tentang peran ulama. Perbedaan itu dapat dilihat diantaranya:

a. Masyarakat pedesaan memiliki keyakinan sangat tinggi bahwa ulama sebagai tokoh yang mampu membawa masyarakat menuju Rahmat Tuhan. Karena ulama orang yang memahami ilmu dan memiliki akhlak yang mulia diyakini bahwa ulama merupakan orang dekat dengan Tuhan sehingga ulama dijadikan jalan atau perantara masyarakat untuk memperoleh rahmat Allah SWT.

b. Masyarakat pedesaan lebih mengutamakan ulama dalam kehidupan sehari-hari untuk menyelesaikan berbagai perma-salahan dibanding aparat pemerintah.

c. Masyarakat pedesaan mempercayai bahwa ulama mampu menyelesaikan permasalahan tidak hanya masalah agama tetapi berbagai permasalahan baik sosial maupun ekonomi.

d. Kepercayaan dan keyakinan merupakan latarbelakang masyarakat pedesaan menjadikan ulama sebagai tokoh yang sangat penting.

e. Masyarakat kota memandang peran atau tugas ulama dibatasi dalam lingkup agama saja, seperti membimbing dan mengajarkan syariat 
Islam, menyelesaikan permasalahan hak waris dan mengobati penyakit seperti kesurupan.

f. Masyarakat perkotaan menem-patkan posisi ulama sama pentingnya dengan aparat pemerintahan.

g. Masyarakat perkotaan tergolong masyarakat modern yang cenderung berpikir rasional, yang berpengaruh pada pemosisian fungsi ulama hanya pada ranah keagamaan. Adapun masalah di luar kontek agama mereka meyakini ada intitusi lain yang bertugas untuk menyelesaikan.

\section{Simpulan}

1. Masyarakat pedesaan tepatnya di desa Cibitung memahami ulama yaitu sebagai tokoh yang menjadi panutan yang mengajarkan dan membimbing masyarakat dalam kehidupan. Masyarakat pedesaan memahami peran ulama sangat penting karena ulama diyakini sebagai tokoh yang dapat memberikan solusi dalam berbagai persoalan yang dihadapi oleh masyarakat baik persoalan agama, sosial dan ekonomi. Sedangkan masyarakat perkotaan yang berlokasi di Kel. Cibangkong kota bandung menjelaskan bahwa pemahaman tentang ulama, mereka memahami ulama merupakan seorang yang mengerti hukum yang dapat membimbing masyarakat dalam bidang keagamaan. Adapun dari segi pemahaman peran ulama masyarakat perkotaan sedikit bergeser pemahamannya bahwa peran ulama hanya dalam persoalan-persoalan keagamaan.

2. Masyarakat pedesaan memahami pentingnya peran ulama dalam kehidupannya, ulama yang dapat memberikan pengetahuan tentang berbagai persoalan yang di hadapi di dunia. Maka untuk menjaga supaya kedekatan antara masyarakat dan ulama bisa terus berjalan dan masyarakat bisa terus mendapat pemahaman dari ulama, salah satunya dengan terus megikuti kegiatan-kegiatan keagamaan, dan supaya generasi ulama tetap ada untuk selanjutnya maka mendidik anak dipesantren merupakan salah satu cara dalam mempertahankan peranan ulama. Sama halnya pemahaman masyarakat perkotaan bahwa untuk mempertahankan peranan ulama maka salah satu cara dengan mengadakan tablig akbar, memakmurkan masjid dengan diisi kegiatan-kegaiatan keagamaan. 


\section{DAFTAR PUSTAKA}

Dhofier Zamakhsyari, Tradisi Pesantren, (Jakarta, LP3ES anggota IKAPI, 2015) Rozak Abdul, H. Dr. Prof. dkk, Ilmu Kalam 2, (Bandung, CV Galuh Nurani 2011) Rozak Abdul, H.Dr. Prof., Anwar Rosihan, H. Dr. Prof, Ilmu Kalam (Bandung, Pustaka Setia 2014).

lum Bahrul, Dr., Ulama dan Politik (Yogyakarta, Pustaka Pelajar, 2015).

Nina W. Syam M.S Dr. Prof., Filasata sebagai Akar Ilmu Komunikasi, (Bandung, 2013).

Horikosi Hiroko, Dr., Kyai dan Perubahan Sosial, (Jakarta, Perhimpunan Pengembangan Pesantren dan Masyarakat, 1987).

Moeloeng Lexy. J, Metodologi Penelitian Kualitatif, (Bandung, PT Rosdakarya, 2006).

Supardi, Metodologi Penelitian Ekonomi dan Bisnis (Yogyakarta, UII Press, 2005).

Ahmad Tanzeh, Sugiyono, Dasar-dasar Penelitian (Surabaya, Elkaf, 2006).

Sugiyono, Memahami Penelitian (Bandung, CV Alfabeta, 2005).

Ridwan, Statistika Untuk Lembaga dan Instansi Pemerintah/Swasta (Bandung, Alfabeta, 2004).

Abdurrahman, Fatoni, Metodologi Penelitian dan Teknik Penyusunan Skripsi (Jakarta, PT. Rinekha Cipta, 2006).

Zuriah Nurul, Metodologi Penelitian Sosial dan Pendidikan (Jakarta, PT Bumi Aksara, 2006).

Mulyana Deddy, Metodologi Penelitian Kualitatif (Bandung, Remaja Rosdakarya, 2004).

Sugiyono, Memahami Metode Penelitian Kuantitatif,

Kualitatif (Bandung, Alfabeta, 2008).

Ridwan, Hasan Al-Banna, Al-Aqaid (Alih bahasa Salim Mahud), (Surabaya, 1981).

Badaruddin Hsukby, Dilema Ulama Dalam Perubahan Zaman (Jakarta: Gema insani Press, 1995).

Muhamad Nur Aziz, Peran Ulama dalam Perang Sabil di Ambarawa Tahun 1945 (Skirpsi tidak diterbitkan, Jurusan Sejarah dan Kebudayaan Islam Fakultas Adab IAIN Sunan Ampel Surabaya).

Rosehan Anwar, dkk, Ulama dalam Penyebaran Pendidikan dan Khazanah Keagamaan (Jakarta: Proyek Pengkajian dan Pengembangan dan Lektur Pendidikan Agama, 2003).

Yayan Nurbayan, Karakteristik Ulama Menurut Al-hadist, 1999. Diakses pada hari Kamis, 7 Desember 2017. 
JAQFI: Jurnal Aqidah dan Filsafat Islam, Vol. 4, No. 1, 2019 | h. 78-104 Paridah Napilah, Ahmad Gibson Albustomi. | p-issn 2541-352x e-issn 2714-9420

Muhtarom, Reproduksi Ulama di Era Globalisasi (Yogyakarta: Pustaka Pelajar, 2005).

Moch. Eksan, Kyai Kelana: Biografi KH. Muchith Muzadi (Yogyakarta: LKis. 2000).

Ahmad Adaby Darban, Ulama Jawa Dalam Persepkitif Sejara, Vol. 16, 2004. 